\title{
大船渡町の防火建築帯指定後の展開 \\ CONSTRUCTION AFTER APPLICATION OF \\ THE FIREPROOF BUILDING BELT IN OFUNATO TOWN
}

\author{
速 水清 孝*1
}

Kiyotaka HAYAMI

The purpose of this study is to clarify the development of the construction on the Fireproof Building Belt (FBB) in Ofunato Town after the Chilean Tsunami of 1960. The results are as follows:

1. Construction of fire-resistive buildings had hardly progressed on FBB.

2. The shopkeepers in Ofunato Town understood the necessity of the appropriate buildings to create their new era. However, they could not construct them due to the lack of their financial power.

3. Some buildings were constructed on FBB were used as Tsunami Evacuation Building at Great East Japan Earthquake of 2011. In that sense, FBB was effective.

\section{Keywords: the Chilean Tsunami of 1960, Reconstruction, Local Cities, Ofunato Town, the Fireproof Building Promotion Law, the Fireproof Building Belt \\ チリ地震津波，復興，地方都市，大船渡町，耐火建築促進法，防火建築帯}

\section{1. はじめに}

岩手県大船渡市大船渡町は、1960（昭和 35）年 12 月 17 日、防火 建築帯に指定された最後の都市である。既報注1) ではその大船渡に なぜ防火建築帯が指定されたのかを探り、防火建築帯に防火以外に も多様な活用法があると確信する建設省が、当時、この都市が臨海 工業都市として成長の見込まれる中で、チリ地震津波被害からの復 興の施策に、防潮帯の意味を込めて指定したことを示した。

しかし大船渡は、現在の眼で見れば、その後、東日本大震災（以 下、震災。2011）の津波で再び大きく被害を受けた都市でもある。 それを考えると、指定された防火建築帯がそこでどのように機能し たかは興味深い。これについて得るものとしては、都市計画史を専 門とする中島直人らが、防火建築帯が指定された大船渡町の沿岸部 に、震災後に残った建物を簡単に記したものや注2)、建築防災が専門 の森山修治らが、震災時の大船渡町の津波避難ビルについて調べた ものがあるが注3)、いずれも防火建築帯の範囲との照合を欠いている。 また、それ以前のこと、すなわち、大船渡の防火建築帯の構想に 対して地元がどのように反応したのかについても、指定後、その範 囲にどのような建物が建ったのかという造成の実態についても、一 部既報に記した他に判明することはほとんどない。市史注4) はもち ろん、チリ地震津波とその後を扱った文献にこれらに関する記載は ほぼなく、得る限りでは、『大船渡市市勢要覧』(1968) が、「この禍 いを契機に、狭くて曲りくねっていた街路を拡張舗装して街路樹を
植え、今にみるような近代的な店舗が軒を連社、活気に満ちた商店 街に衣がえをしました」注5) と記すものがある程度である。

そこで本稿では、議会や行政などの公文書に、新聞記事や地図、 当時の各種の調查資料を用いて、大船渡市の防火建築帯の造成の実 態を、まず、(1)地元の状況に注目しながら、指定に向かう時期につ いて、次に、(2)指定後の初期の展開について探る。その上で、(3)震 災に向かう中でその周辺に起きた変化を明らかにする。

本稿に関寸る先行研究の状況については既報に記した通りである。 防火建築帯に関する研究は、多くが指定の前後か、建設から時間が 経った近年を対象としたものであり、本稿のように指定から近年ま でを俯瞰しょうとするものは見当たらない。

ところで、防火建築帯の根拠となる耐火建築促進法は1961（昭和 36）年 6 月、防災建築街区造成法に改まる。そのため、防災建築街 区造成法制定後については、防火建築帯であった防火地域の範囲を 防火建築帯と呼ぶことは不適切であるが、本稿では混乱を避けるた め、1961 年以後についても便宜的に防火建築帯と呼ぶことにする注6)。 なお、本稿の一部は 2021 年度日本建築学会大会で発表しており注

7)、本稿はそこに大幅に加筆し、再構成を施したものである。

\section{2. 大船渡町の商店街の状況}

\section{1. 大船渡町の商店街の被災後の動き}

まず、チリ地震津波被害からの復興策としての防火建築帯の構想 
を地元がどう捉えていたかを見ると、既報に示したように、行政や 地元紙『東海新報』は、構想の登場以来一貫して前向きに評価した。 その他一般の市民も、被災した台町・赤沢両地区の住民が、防火建 築帯の構想範囲から当該地区が漏れたことを市に翻意するよう求め たように、前向きに捉えた。ただし、ここでの一般市民は、多くが 建設を専門としないだろうから、評価の前提となる建設に当たって のイメージがどれだけ正確にできているかという点に疑問はある。

一方、その主な指定範囲は商店街が中心となる。そこで建築主に なる商店主たちは、どう捉えたのだろうか。被災直後から見ていく。

被災からちょうど 1 ケ月を経た 6 月 24 日の『東海新報』は、 7 月 1 3 日に東京都商工指導所の登録中小企業診断員を講師に招いて、 「災害地における商店の復興ならびに店舗の改装新築についての講 習会」が開かれると報じた注8)。また、最終日の 3 日には、夏の大売 出しを前に、町民に地元商店街での買い物を促すため、大船渡専門 店会が宣伝車を購入すると記している湦9)。

いずれも背景となる動機には復旧・復興があった。しかし、前者 の講習会では、それ以上に目的を、「交通機関の発達による管外の、 大資本業者が機動力によつて市内に食い込んでいることと、さらに 市内の人たちが、出先都市での購買、また地元消費の事業意欲が不 足な関係で、市外に流れる金額が多いとみている」ためとするのが 興味深い。この点については、この頃の商店街を取り巻く状況を垣 間見ることができるものでもあるので、後に再び触れることにする。

ちなみに、東京都商工指導所の診断員は、この講習に合わせてこ のとき市から商店街の簡易診断を依頼されている。その診断結果は、 既報で述べたように、高台に移転して新たに商店街を造り直すので はなく、現位置での復興を説くものであった注10)。

これに続いて大船渡商工会議所は、9 月にも、市と共催で、市内 の商店街に近代的なセンスを与えようと注11)、外部に商店街の診断 を依頼し、町内の 19 店に対して店舗の構成や陳列方法などの指導を 行った注12)。また、最終的には頓挫するものの、年が改まってから は中央の人気グループ、ザ・ピーナッツを招くことを予定した注13)。

Table1 Perspectives to the Future by Shopkeepers (1961)

\begin{tabular}{|c|c|c|c|c|c|c|c|c|c|}
\hline & \multicolumn{3}{|c|}{$\begin{array}{l}\text { Ofunato Town } \\
\text { 大船渡町 }\end{array}$} & \multicolumn{3}{|c|}{$\begin{array}{c}\text { Sakari Town } \\
\text { 盛町 }\end{array}$} & \multicolumn{3}{|c|}{$\begin{array}{l}\text { Total } \\
\text { 全体 }\end{array}$} \\
\hline & $\mathrm{n}$ & $\%$ & $\%$ & $\mathrm{n}$ & $\%$ & $\%$ & $\mathrm{n}$ & $\%$ & $\%$ \\
\hline $\begin{array}{l}\text { will great } \\
\text { develop } \\
\text { 大いに発展す } \\
\text { るだろう }\end{array}$ & 59 & 49.6 & 95.2 & 3 & 4.4 & 4.8 & 62 & 33.2 & 100 \\
\hline $\begin{array}{l}\text { still have } \\
\text { potential for } \\
\text { develop } \\
\text { まだ発展の余 } \\
\text { 地はある }\end{array}$ & 37 & 31.1 & 47.4 & 41 & 60.2 & 52.6 & 78 & 41.7 & 100 \\
\hline $\begin{array}{l}\text { will not change } \\
\text { much } \\
\text { あまり変わら } \\
\text { ない }\end{array}$ & 17 & 14.3 & 58.6 & 12 & 17.7 & 41.4 & 29 & 15.2 & 100 \\
\hline $\begin{array}{l}\text { will be a little } \\
\text { depressed } \\
\text { やや衰微する } \\
\text { だろう }\end{array}$ & 3 & 2.5 & 21.4 & 11 & 16.2 & 78.6 & 14 & 7.5 & 100 \\
\hline $\begin{array}{l}\text { will be great } \\
\text { depressed } \\
\text { 大いに衰微す } \\
\text { るだろう }\end{array}$ & 0 & 0.0 & 0.0 & 1 & 1.5 & 100 & 1 & 0.5 & 100 \\
\hline D.K & 2 & 1.7 & 100 & 0 & 0.0 & 0.0 & 2 & 1.4 & 100 \\
\hline N.R & 1 & 0.8 & 100 & 0 & 0.0 & 0.0 & 1 & 0.5 & 100 \\
\hline Total & 119 & 100 & 63.6 & 68 & 100 & 36.4 & 187 & 100 & 100 \\
\hline
\end{tabular}

こういった一連の取り組みは、その他の要素も含むだろうが、まず は、復旧・復興に向けて考案された、地元商店主たちなりの施策と 捉えることができる。

\section{2. 大船渡町の商店街の防火建築帯への期待}

こうした取り組みをさらに探すと、1961（昭和 36）年 11 月に県 と大船渡市と陸前高田市が、社会学者の佐藤智雄 (中央大学教授) に委託して気仙地方の商店街を対象に行った調查報告が見つかる注 14)（Table1）。ここではまず、商店主たちの将来への見通しとして、 大船渡町は「大いに発展するだろう」を $49.6 \%$ が選んでいることが 目を引く。これは、このとき市の二極の片方であり、かつての中核 だった盛町が $4.4 \%$ であるのと対照的である。

調查の緒言では、「市街地のめぬき商店街では、急激にみごとな復 興を示してきている」注15) とする一方で、今後の発展のために必要 なものとして、大船渡町・盛町の両商店街ともに「工場・住宅の建 設」を、次いで「商店街の町づくり」を課題に上げた注16)。そして、 「商店街発展のために、アーケード架設、道路の埔装、街路灯、ネ オンなど金のかかる計画を立てたらとしたら、あなたはそれに協力 の必要があると打考えですか」と尋㸚たところ、大船渡町・盛町と もに、「絶対必要だ」が過半を占め、設備投資を不可欠と見ていた。 続いて、自動車交通量の増える中で、1968（昭和 43）年に県・市・ 商工会議所が行った商業診断報告書もある注17)。ここでは、大船渡 地区について、商業の発展に向けて「ブロック毎に共同店舗化、あ るいは共同建築化、あるいは非店舗や飲食店の立体化」が望まれる と、加えて「共同店舗を商業地の核として造成していくことを構想 しなければならない」との提言もなされた。つまり、行政や商工会 議所は、共同店舗化や共同建築化を望んだことになる。これらの共 同化の前提には、鉄筋コンクリート造による耐火建築物があること になるはずである。

この報告書では、この他、総括に「商業地が路線的でなく街区的 に形成されていく傾向に大船渡市の商店街も考え方を変えていく心 き」と記された。すでに面的防火の時代に入り、他の都市では登場 寸る新しい建築のあり方を採り入れるべきとの提言である。

そうした目で見ていくと、共同建築は、もつと早い時期に、市や その周辺から、啓蒙の意味も含めて推進する声が上がっていたこと に気づく。例えば被災直後の『東海新報』は、他市にあるような「1 つの屋根の下でそれぞれ独立した店舗が集ま」り「商店街が施設を 充実し、横のデパート化をはかり、商店の集団化をはかる」ことを 説き注18)、また、市災害復興事務局長の広沢登米夫は、その実現を 期待して、この復興期を、「都市美と名店街の充実を図り、集団の力 で魅力のある商店街建設の絶好の機会」と捉える言葉を残した注19)。

\section{3. 大船渡町の商店主たちの状況}

しかしその、前者 1961 年の調査で、商店主たちは、経営上最も困 っている点に資金難を上げてもいる注20)。考察には「チリ地震津波 により商店街の大半が被害を蒙り、現在商品の充実まで資金が及ん でいないことが一般的傾向であることからも、まず第一に資金難が あげられることは当然のことであろう」とあり、被災から 1 年半経 っても商品の充実すら覚束ないことが指摘されていた。

その前提を知るため、この地域に住む人たちの背景を見ておきた い。チリ地震津波の被災後、大船渡町を訪れた菅原貫一（全国中小 企業等協同組合中央会）は次のように書いている。 


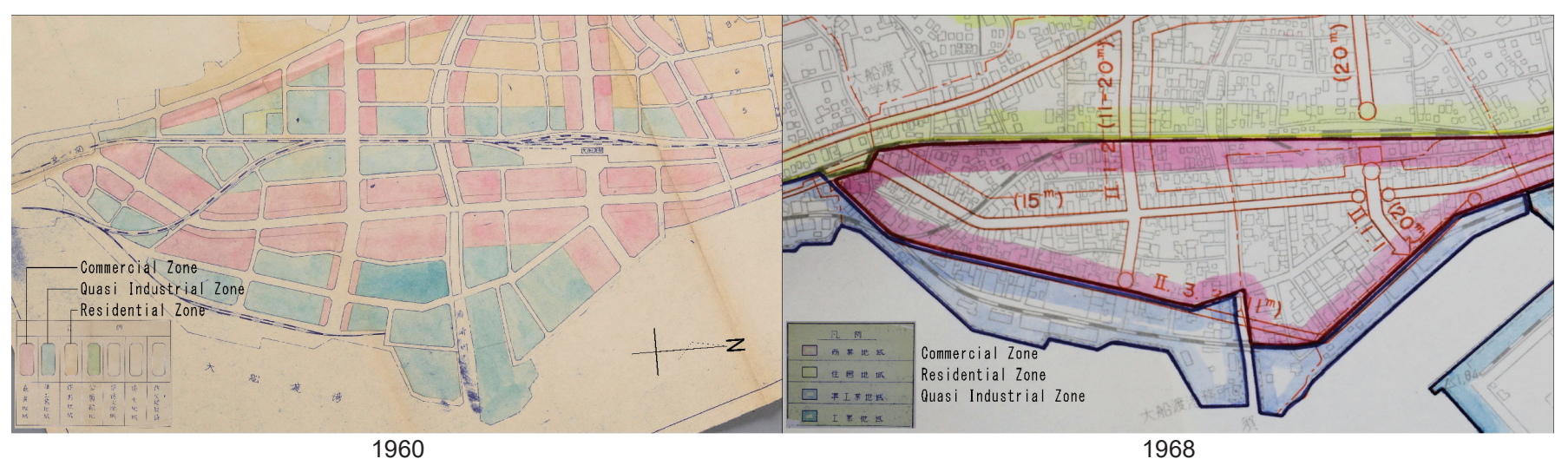

Fig.1 Land Use Zone in Ofunato Town

Source: National Archives of Japan

大船渡中央マーケット協同組合の菅理事長を訪れる。この組合 は終戦後引揚者、戦災者が幾多の苦心、試練を乗り越えてよく奮 闘して団結を固くし、現在の近代的設備を誇る立派な共同販売店 舗を建設したが、新装間もなくこの大津波、浸水は 2 階まで達し て商品は勿論、陳列施設一切は瞬時に流失して残つたのは泥と污 物だけだつた。注21)

他に、『岩手日報』も、「古いノレンを誇る盛町に対抗して新興商 店街を形成していた大船渡町」と評した注22)。こうした記述から、 昭和三陸津波（1933）・大船渡町大火（1943）なざたびたび災害が襲 う場所に、終戦後引揚者や戦災者も加わり、総じて経済的に余裕の ない者たちが苦心しながら商売を営むこの町の実像が見えてくる。

商店主たちは、前述のように被災以来様々な取り組みをし、共同 建築化を望む声も確かに上げた。しかし、こうした経済状況下にあ る彼らに、鉄筋コンクリート造建物の建設費に対する不安はあった に違いない。また、防火建築帯構想の当初、建設省が大船渡では経 済地理的な状況から単独での建築を認める態度を示したように注23)、 共同建築に対する躊躇もあったかも知れない。

前稿でも示し、また改めて後述するように、チリ地震津波の後に も住宅の高台移転は進んだ。その傍らで、復興に当たって大船渡町 では現位置での復興も進められた。そのための施策の 1 つが防火建 築帯だったのであり、その敷設範囲は、商業地域と準工業地域とな った (Fig. 1 左)。そこに建つものは、この当時の商店や工場の形態 から寸れば、多くは併用住宅となることが想定されただろう。した がって、専用の住宅は高台に移ったとしても、併用の住宅はそこに 残ったことになる注24)。

それでもこの後、徐々に、店舗などの併用住宅がそのままの形で 繁栄していける時代ではなくなっていく。事実、1961 年の調查が行 われた直接的なきっかけは、台頭しつつあった全国チェーンのスー パーマーケットの進出であった注25)。新たに現れた店舗形態が町に 現れ、好評を博す中で、これにどう対抗し、地元商店街をどう生き 永らえさせるかという視点が反映されたものである。

1961 年と 68 年の調查の間、大船渡市の経済は、工業開発拠点都 市としての面目を躍如するかのように順調に伸びていた注26)。そう であっても、「企業内部についてみると、零細規模のものが多く、経 営の多くは生業的な色彩が強く豊富な労働力に支えられた低賃金経
営のものがその大部分を占めている」とも報告された注27)。となる と、先細りに向かうことが予想され、結果として、それ以前から資 金難にあえいできた地元商店街に、鉄筋コンクリート造の耐火建築 物や、その共同建築での実現は、望んでも、できる状況はより以上 になくなっていたと考えるのが自然である。

『市勢要覧』（1972）の次の記述から、市内の商店街は、昭和 40 年代半ばに至っても零細な小売店舗がほとんどだったことが分かる。

昭和 45 年度の商業統計調査からみますと、人口 4 万人に商店数 982 は、岩手県平均より上廻っています。従って一店舗当りの販 売額は（略）、岩手県平均より約 $17 \%$ 下迴っています。注28)

\section{3. 防火建築帯への建設}

\section{1. 防火建築帯の範囲の既設耐火建築物}

地元の経済が必ずしも好調でない中をチリ地震津波が襲い、その 復興にあたって、前稿に示した東北開発研究会の報告注29) をはじめ 地方の識者たちも堅固な構造を求める中でもたらされたのが、耐火 建築物の建設を促す防火建築帯の構想であった。

本章では、その防火建築帯への建設活動を探るが、その前に本節 では、指定以前の大船渡町にはどのくらい耐火建築物があったのか を見ておくことにする。

1960 (昭和 35）年 12 月に防火建築帯の指定を受けた際、その造 成計画では、既存の $430 \mathrm{~m}$ に加えて、1960（昭和 35）年度には 280

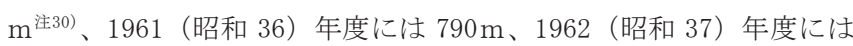
$360 \mathrm{~m}$ の計 $1,430 \mathrm{~m}$ の耐火建築物の建設が想定されていた（Fig. 2)。 ただし、既存の耐火建築物が $430 \mathrm{~m}$ もの間口長さで建っていたか については念のため確認すべきだろう。1960 年の指定申請書の造成 計画図 (Fig. 2) で防火建築帯の範囲に既存の耐火建築物が建つと示 されるのは、駅前の街区を囲むように 6 ケ所、そこから伸びていく 道路の両側に 4 ケ所の計 10 ケ所ある。これを同じ申請書の現況図 (Fig. 3) と照合すると、耐火建築物であることが確認できるのは 4 ケ所に 4 軒あるのみである。同じ申請書の資料であるにもかかわら ず食い違いのある理由は分からない。それでも、Fig. 3 からはその 4 軒の規模が、おおよそ建築面積は小さく、間口長さも短いことが分 かる。詳細に見ると、駅に近い 2 軒は敷地一杯に建つものの、駅か ら離れた 2 軒の敷地は広大である注31)。したがって、Fig. 2 の既存の 


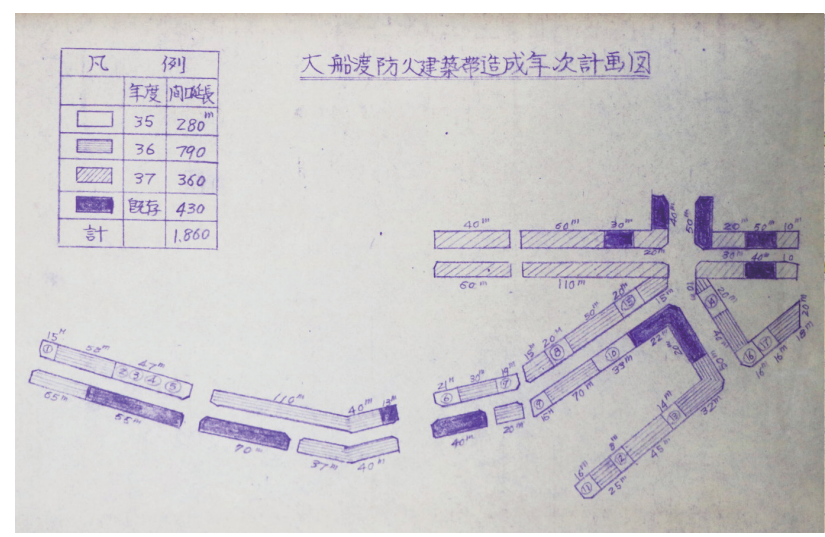

Fig.2 Annual Construction Plan of the Fire Proof Building Belt in Ofunato Town (1960)

Source: National Archives of Japan

耐火建築物の間口長さは、敷地内に耐火建築物がある場合には敷地 の間口全てを既存長さと見て算出されたものとなる。これは間口長 さの計算上、ある意味では当然であるが、ともあれこの範囲には、 もともと耐火建築物自体さして建っていなかったことが分かる。

\section{2. 統計資料からみた大船渡市の建築活動}

上のような中で、とはいえ防火建築帯の指定によって耐火建築物 としての鉄筋コンクリート造建物の建設が進められていくことにな る。その際の大船渡市全域での建設活動を、防火建築帯の指定の前 後に注目して、統計資料から見ていく。

これについて、1963（昭和 38）年に大船渡消防署が報告した過去 5 年間の建築確認に対する消防同意の変遷を見ると（Table2）、チリ 地震津波直後の 2 年間には、その前後に比べて活発な建設活動があ ったことが分かる。

次に、市制施行後 20 年間の大船渡市全域の建設状況を、統計資料 から床面積に注目して示したのが Fig. 4 である。当初捗々しくない 建設は、1959（昭和 34）年からが活発になり、チリ地震津波からの 復興の時期に急増する。その後いったんは減るものの、再び、おそ らくは高度経済成長の後押しによって増に転じていく。

ちなみにこの、活発になり始める 1959 年以前の構造は、ほぼ木造 である。また、この図では簡略化のため、全期間を通して量の少な い鉄骨鉄筋コンクリート造・コンクリートブロック造を鉄筋コンク リート造に含めて示したが、これら鉄筋コンクリート造等の建設は、 1961（昭 36）年より増え始め、1964（昭和 39）年にピークを迎える ものの、その直後より減っていく。このことから、チリ地震津波後 の防火建築帯の指定は、大船渡市の鉄筋コンクリート造建物の建設 推進に一定程度寄与したことが分かる。その後、増えていくのが鉄 骨造である。よって、耐火建築物としてはほどなく鉄筋コンクリー 卜造から鉄骨造に代わっていくことになる。

\section{3. 防火建築帯周辺の建設の申し込み（指定前）}

前節では、大船渡市全域の建設の動向を見た。しかし、市全域で は、対岸の旧赤崎町や南の旧末崎町など様々な地域の建設活動が含 まれてしまう。そこで、本節では大船渡町に絞って、その構想の初 期から、防火建築帯周辺への耐火建築物の建設希望者がどの程度あ ったのかを、『東海新報』などから探ることにする。ただし、記事に よって基準などが異なるようで、申し込みや建設の件数の推移が一 様に俯瞰できるものにはなりにくいが、Table3にこれを一覧にする

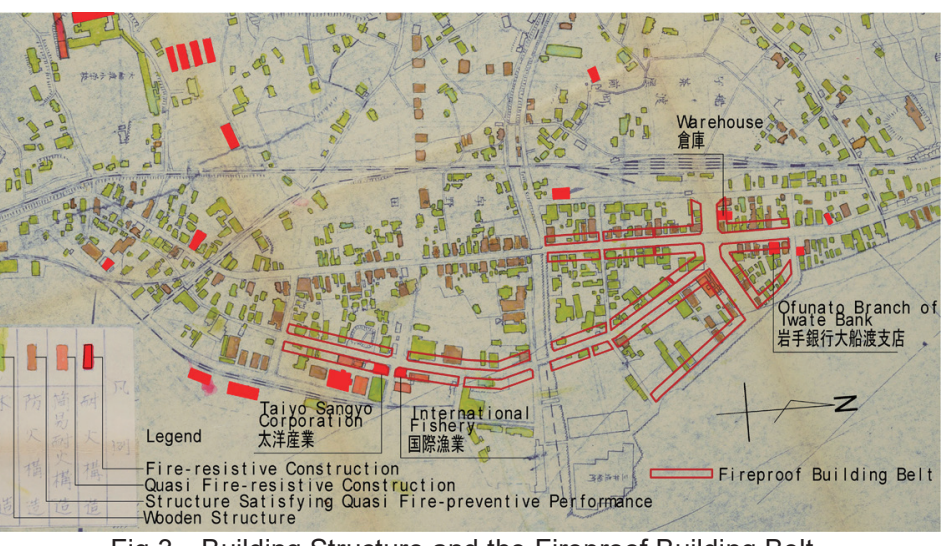

Fig.3 Building Structure and the Fireproof Building Belt in Ofunato Town (1960)

Source: National Archives of Japan, Emphasis added by the Quoter

Table2 Consent of the Chief of Ofunato Fire Station

\begin{tabular}{c|c|c|c|c|c}
\hline Year & 1958 & 1959 & 1960 & 1961 & 1962 \\
\hline n.of Consent & 239 & 263 & 425 & 374 & 239 \\
\hline
\end{tabular}

Source: Ofunato City: City Directory, p.82, 1963 (the Univ. of Tokyo Library)

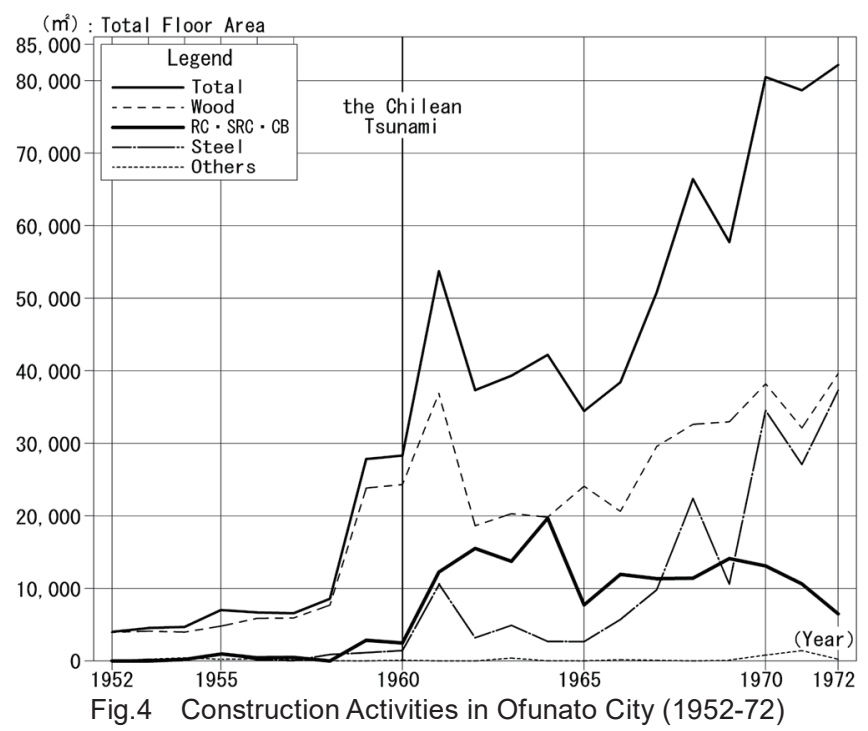

Source: Ministry of Construction: Annual Report of Building Construction, 1952-73

Table3 Application for Subsidy and Loan against the Fireproof Building in Ofunato Town

\begin{tabular}{|c|c|c|c|c|c|c|c|c|c|}
\hline \multirow{2}{*}{\multicolumn{3}{|c|}{$\begin{array}{c}\text { Year } \\
\text { Month/Day }\end{array}$}} & \multicolumn{3}{|c|}{1960} & \multicolumn{3}{|c|}{1961} & \multirow{2}{*}{\begin{tabular}{|c|}
1962 (total) \\
$-3 / 31$ \\
\end{tabular}} \\
\hline & & & $6 / 30$ & $7 / 26$ & $11 / 27$ & $1 / 11$ & $2 / 1$ & $2 / 28$ & \\
\hline \multirow{2}{*}{\multicolumn{2}{|c|}{ Application }} & Whole Town & 35 & - & - & - & 20 & 20 & 21 \\
\hline & & Inside FBB & 17 & 12 & 14 & 4 & 9 & - & - \\
\hline \multirow{3}{*}{$\begin{array}{l}\text { Construc } \\
\text {-tion }\end{array}$} & Start & & - & - & - & 12 & - & 10 & - \\
\hline & \multirow{2}{*}{$\begin{array}{l}\text { Comple } \\
\text {-tion }\end{array}$} & Whole Town & - & - & - & 1 & - & - & - \\
\hline & & Inside FBB & - & - & - & 1 & - & - & 8 \\
\hline
\end{tabular}

FBB: the Fireproof Building Belt

Source: Tohkai Shimpo, 1960-62 (Ofunato City Library) and Kaneno, K: Record of Disaster of the Chilean Tsunami, Ofunato City, p.180, 1962

ことを試みて、それぞれの時点で現れた件数と 1961（昭和 36）年度 末までの計を示した。以下、この表に沿う形で述べていく。

既報で示したように、市の議論は、1960 年 6 月 16 日の第二回災 害復興対策委員会に始まる。この場では、県建築課長の青江邦良が 中高層建築物に対して住宅金融公庫が融資を検討していると、また、 市が積極的に補助を考えていると述べた注32)。ここで中高層建築物 とは「鉄筋 3 階以上のビル」を指す。これらは、この時期の大船渡 にとっては防火建築帯があってこその建設となるが、この時、市災 
害復興事務局長の広沢は「市街地に百棟ぐらいのビルが立ち並べば 防災と美しさをかね衫た立派な市街地ができるのだが」と語っている から、防火建築帯の構想に明るい未来を描いていることが分かる。

住宅金融公庫の中高層建築物への貸付条件が示された同月 30 日注 33)、市に建設の申し込みが 35 件あった注34)。内訳は「茶屋前 [11]、 須崎 6、赤沢 6、明土 3 、台町 6、笹崎 $3 」$ で、延べ面積は $12,279.3$ $\mathrm{m}^{2}$ 、総建設費は 2 億 1 千万円となった。申込者の業種はほとんどが 商店だったが、中には貸事務所も数件あった。規模はいずれも 3 階 建てで、延べ面積は 198〜841. $5 \mathrm{~m}^{2}$ （60〜255 坪）だった。この時期 にはまだ、防火建築帯の敷設範囲も茫漠としているため、これを最 終的な範囲に限ると、「茶屋前 [11]、須崎 $6 」 の 17$ 件となる。

7 月 26 日、防火地域の指定について市が建設省に陳情に行くと報 じる記事の中に、次のように防火建築帯の長さと具体的な敷設範囲 とともに、中高層建築物の建設希望者が 12 件あると示された。この 中には希望者名と建物の規模も具体的に記されており、それを見る と、規模については、小は 65 坪から大は 1,100 坪までと幅広かった。

市当局案によると、同町内の笹崎から赤沢に至る災害地域を準防 火地域とし、主要箇所に防火帯を設定しょうというもので総延長 千百メートルを予定 (略)。この防火地帯設定の予定地域内から中 高層建築を希望しているのは目下のところ 12 件となつており、市 では住宅金融のワク獲得にも努力することになつている。

中高層建築希望者および坪数次の通り。(略) 注 35$)$

この後、防火建築帯への中高層建築物の建設申し込みにまつわる 話題はしばらくのあいだ紙面から消えるが、指定が近づいた 11 月 15 日、再び登場する注36)。そこでは、住宅金融公庫仙台支所が融資 申込者の最終審查をしている最中であり、防火地域指定の報を待っ て正式に貸付けを決める意向と報じられた。

このように、次第に防火建築帯の指定が目に見えてくる中、市長 の鈴木房之助は、チリ地震津波の復旧・復興対策が「伊勢湾台風復 旧対策よりも軽視されている」として、県内沿岸市町村と津波対策 協議会を結成し、副会長となる。続いて、政府に、対策事業の早期 完成と高率の国庫補助・地方債の発行を求めて 24 日上京し、関係各 方面に陳情した。それとともに、最終査定のために 28 日に開かれた チリ地震津波対策審議会でも、これらを強く要望した注37)。

この時期の市長の奮闘ぶりを広沢は「おら方の市長は大したもん だ」と評した注38)。具体的には、災害復旧対策事業の交涉の場で、「伊 勢湾台風なみに国庫補助率を 2 分の 1 を 3 分の 2 、または 8 割まで 高めて欲しい」との陳情に対して、「チリ地震津波程度のものはいく らでもある、いちいち 8 割補助を出せない」注39) と応じる大蔵省の 主計長に、「東北を冷遇しすぎる、伊勢湾なみの工事ができないこと があるか」と「激しい闘志で立ち向か」注40) ったことを挙げる。

こうした姿勢が奏功したのか、建設省が示した大船渡市の防火建 築帯構想は、大蔵省に好意に受け止められて、国庫補助率は市長が 求めた通り 3 分の 2 となった注 41 。 それればかりか、大蔵省は建設省 より遥かに積極的で、「35、36 年度の両年度に完成するよう希望」 し、計画の再検討を迫られた建設省は、急いで資料を揃えるよう市 に求め、市建設課長の新沼堯範が 27 日上京する事態となる注42)。

こうして指定を待つばかりとなった地元では、せっかくの好条件
を活かそうと、12月 14 日には商工会議所で改めて説明会を開くな ど、希望者の勧誘に動いた。というのも、いざ指定の見えてきた 11 月 27 日の時点で、 35 年度に防火建築（中高層建築）を予定してい るのは、わずか $14 、 5$ 件に過ぎない」状態だったからである注43)。

\section{4. 防火建築帯周辺への建設（指定直後）}

次に、防火建築帯の指定後である。12月 25 日の『東海新報』は、 「貸付 2 件がまず決定」と題し、その詳細を「太洋産業株式会社の 社員宿舎と米谷貫二氏のマーケットの 2 件」と報じた注44)。また、 年が明けた 1 月 11 日には次のようにある。

防火地域の指定に伴なう大船渡町内の防火地帯には鉄筋コンクリ 一ト造りの中高層建築が次々と建てられるが、国の補助をうけら れる建築物はいまのところ林音作商店、菅野秀三商店、東北汽船 港運株式会社、英電社の 4 件と決まり、寸でに東北汽船港運株式 会社の社屋は完成、きょう盛大に落成式があげられる。

また住宅金融公庫に融資を申請中の（略）二階堂商店、太洋産業 株式会社社員宿舎など 8 件と準防火地域に新築予定の宮内善進堂 の融資がこのほど決定、1 月中に設計書を提出、公庫の承認が得 られれば 2 月早々から着工、突貫工事により 3 月末までには主体 構造の完成を期している。これにより 35 年度分として 12 件が防 火建築帯としてお目見えすることになる。さらに 36 年度分として 国は寸でに 1 億 1 千万円の補助額を決めており、市では極力防火 建築を建てるよう勧奨しているが、このため公庫借り入れ希望者 には債務保証をする予定などで、防火帯地域に新築しようとする ものは早急に市建設課に相談するようのぞんでいる。注45)

国庫補助を受けたものは 4 件に留まるが、鉄筋コンクリート造の 中高層建築物自体は次々と防火建築帯上に建ちつつあり、その数は、 1960（昭和 35）年度分として 12 件になる、という。

これに続くものとして、『大船渡災害誌』(1962) には、翌年 2 月 1 日現在の耐火建築物建設の進捗が示され、この時点で 20 戸から申 し込みがあり、うち設計図書まで提出されているのが 9 戸、延坪が 887 坪とある ${ }^{\text {注 } 46) 。 こ の ~} 887$ 坪を、防火建築帯に建設される総 3 階の 建物の延べ面積と考えるなら、887 坪 $\times 3.3 \mathrm{~m}^{2} /$ 坪を階数 3 で除し、 さらに防火建築帯の奥行 $11 \mathrm{~m}$ で除寸れば間口のおよその長さが出

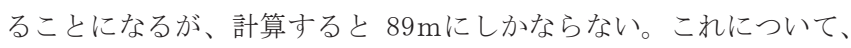
前年 6 月に報じられた住宅金融公庫の貸付対象となる建物には、

イ、耐火構造または簡易耐火構造で地上階数が 3 以上（防火建築 帯内に建設する場合は、地上 3 階以上の建築を予定した構造の 2 階建でもよい）で、その建設物の延床面積のおおむ称 2 分の 1 以 上が住宅であることが必要です。ただし、防火建築帯防火地域又 は準防火地域内の商業地域等に建築する場合で、非住宅部分（店 舗等）の床面積を多くすることが適当な計画となる場合は、住宅 と非住宅の割合いを緩和することができます。注47)

とある。つまり、住宅金融公庫の融資を受けるに当たっては、将来 3 階建てが予定されていれば当初は 2 階建てでもよいとなっている から、多くが 2 階建ての計画だったのかも知れない。また、上で既 存の間口長さについて見たように、敷地の間口一杯に建物が建って 


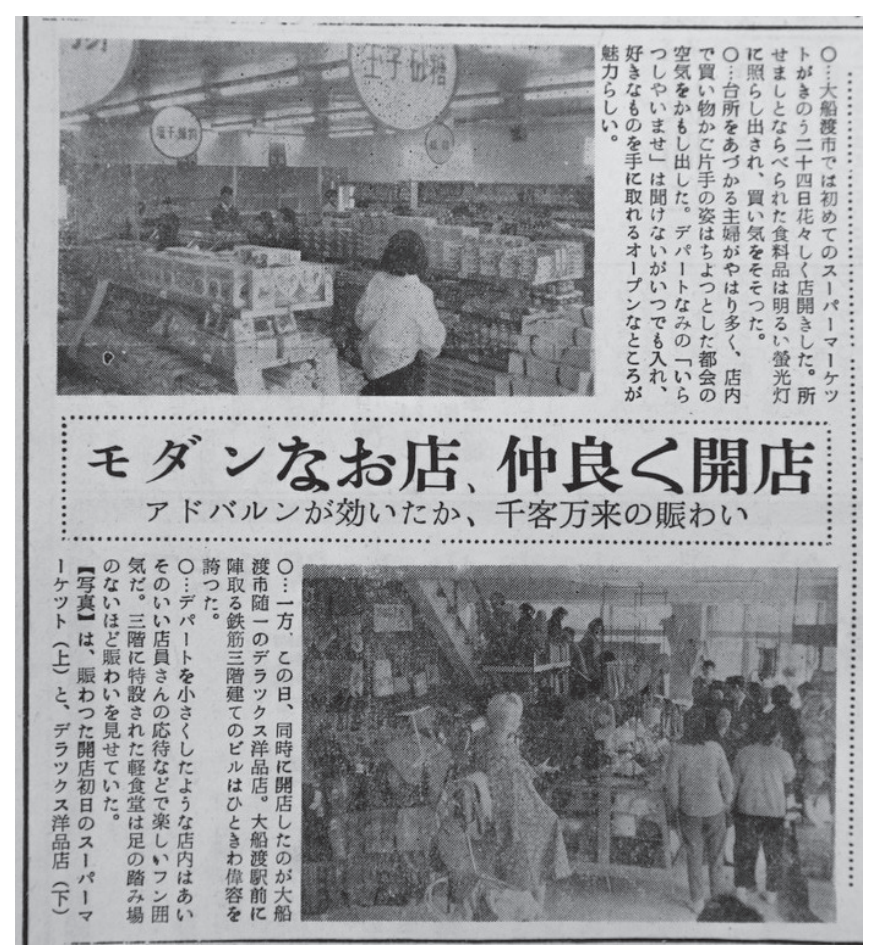

Fig.5 Opening of Two Supermarkets in Ofunato Town (1961)

Source: Tohkai Shimpo, p.1, 1961.4.25 (Ofunato City Library)

いるとは限らない。そう考えると、2 階建てであれば $133 \mathrm{~m} に 、$ 建物

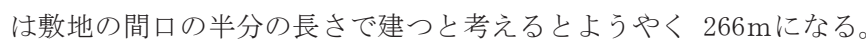
とはいえ、初年度の見込みは $280 \mathrm{~m}$ である。前年 12 月半ばの指定 からここまで 1 ケ月半であるが、年度末までの残り時間を考えれば 必ずしも順調と言えるものではない。『東海新報』は 2 月 28 日、「防 火帯の中高層 まだまだワクに余裕」と題してこう報じた。

大船渡市大船渡町は防災地区に指定され、20 件の建築希望のうち 現在 10 件が工事されている。10 件で国補県、市費合わせて 2,600 万円が消化されるが、この総工費は 1 億円余り。しかしまだ 18 万円のワクの余裕があり、建築希望者をつのつているが、いまだ 決まつておらず、「3月まで消化しろ」との建設省からの督促で大 船渡市建設課は頭痛はち巻きでいる。

新年度予算獲得からもこの国費 90 万円はぜひ消化しなければ といつており、希望者を募集している。注48)

国は、初年度には、被災から 1 年に当たる 5 月末までの申請に限 り、補助率を鉄筋コンクリート造と木造の標準建設費の差額の $1 / 4$ から $1 / 3$ に引き上げる好条件を設けた注49)。一方、市は、指定間際 にもかかわらず申し込みが少ない状態に危機感を覚えて周知に努め 注50)、指定後には再び補助金交付の説明会を催した注51)。それにもか かわらず、用意された補助金は余っていた。

この時期、財政再建団体だった市の財政注52) には負担になったに 違いないが、それでも市は、建設推進のため、さらに「36 年度には できるだけ補助率を高め、防火建築をす寸める方針」を立て、翌 1961 年 3 月の議会で、新たに市による補助制度を設けた注53)。また、5 月 には、市議たちが、中高層建築物や防潮堤・港湾施設の視察のため 富山、伊勢湾台風の復興状況の視察のため名古屋、そして関係官庁
や国会への陳情のため東京に出向いた注54)。こうした動きに見るよ うにこの施策をより推進する意気込みも見せた。

この時期の防火建築帯を含む周辺の耐火建築物の建設量を、『東海 新報』の報道などから把握を試みる。まず、防火建築帯の指定に際 して、大船渡町で中高層建築物の補助や融資に対する申し込みは記 事や広告から数える限り、制度開始初年度（1960（昭和 35）年度） 末までに、上に挙げた 20 件があった（Table 3$)$ このうち初年度中 に 1 件完成したから、残り 19 件は、工期次第だが、建設に至ってい れば、多くは翌 1961（昭和 36）年度の完成になるはずである。

一方、この初年度と 2 年度に防火建築帯に完成した、鉄筋コンク リート造と判明する名称の分かる建物は、まず、第一号として、東 北汽船港運の社屋が、1月 11 日に落成式を迎えた。これが上の初年 度完成の 1 件である。これに続くのが、茶屋前にできた気仙地方で 初めてのスーパーマーケットである林ストア注55) と衣料品のかんの (菅野商店) 注56) で、ともに4月 24 日に開店した（Fig. 5)。その翌 日には細谷薬店注57)、そして、9 月 2 日には完成した米谷ビルに主婦 の店大船渡店が開店する注58)。さらに同月には東海新報社の新社屋 も完成する乼59)、といったように 5 件で、計 6 件あった。

Table1の 1961 年の調查で対象となった大船渡町商店街の商店主 数は 119 である。この調査は全商店の半数を対象としたものであっ たから、全商店数は 238 となる。商店街の範囲と防火建築帯の範囲 は一致しないし、建設申込者は全てが商店主ではないだろうが、乱 暴ではあるものの計算するなら、1961 年度までに完成を迎えた可能 性があるのは 21 件（Table3）で全体の 1 割に満たない。これを防火 建築帯の範囲に限ると上の 6 件に名称不明の 2 件を加えた 8 件で建 物の間口長さは $137 \mathrm{~m}$ となる。これが上の算出のように敷地の間口 半分に建つと考えれば $274 \mathrm{~m}$ である。しかし、いずれにしても、Fig. 2 にある指定後 2 年での造成計画間口長さ計 $1,070 \mathrm{~m}$ には不足する。

それでも、こうした、地方の中小都市としては決して少なくはな いともいえる完成に向けて、工事はラッシュの様相を呈し、年度末 一杯で完成しなければならないところを、作業員の不足や資材の入

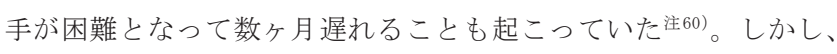
防火建築帯の指定に込めた行政の期待は大きく、そして、決まった 国庫補助消化の点からも、この程度では件数が不足した。市建設課 の「新年度予算獲得からもこの国費 90 万円はぜひ消化しなければ」 との言葉は、その現れである。

前掲『大船渡災害誌』は、その問題の所在を次のように指摘する。

\section{この建築に当っての問題点としては、}

A．建築費が䖉大であり、0.75の融資金の償還が極めて容易でな

く現在の市民経済から見て大衆的でない。

B. 中高層建築費に対する地方公共団体の補助額が多額にのぼり、 地方財政に及ぼす影響が大である。

C．標準建築費が低く実情に合致しない。注61)

この記述は、防火建築帯指定前の、おそらく 11 月以降のものであ る。すでに指定前から建設費が「市民経済から見て大衆的でない」 と認識されていたことになる。しかしながら、Table2 やFig. 4 に示 したように、大船渡市全域の建設活動はそれなりに活発であった。 これはすなわち、防火建築帯以外の市内での建設は、それ以上に進 
んでいたことを意味している。

このように、防火建築帯に完成した建物は盛況を博したものの注 62）、既報で示した商工会議所主催の座談会で、市災害復興対策委員 会都市建設分科会の熊谷長治郎が、「市が補助を出すのに困るほど家 が建つと思うかね」と放った懸念が現実のものとなって、その範囲 への耐火建築物建設の出だしは、好調と言えるものではなかった。

\section{4. 防火建築帯造成の展開}

その後の防火建築帯周辺への建設の動向を探っていく。ただし、 年ごとの進捗の全容が分かる資料は見当たらない。そのため、これ

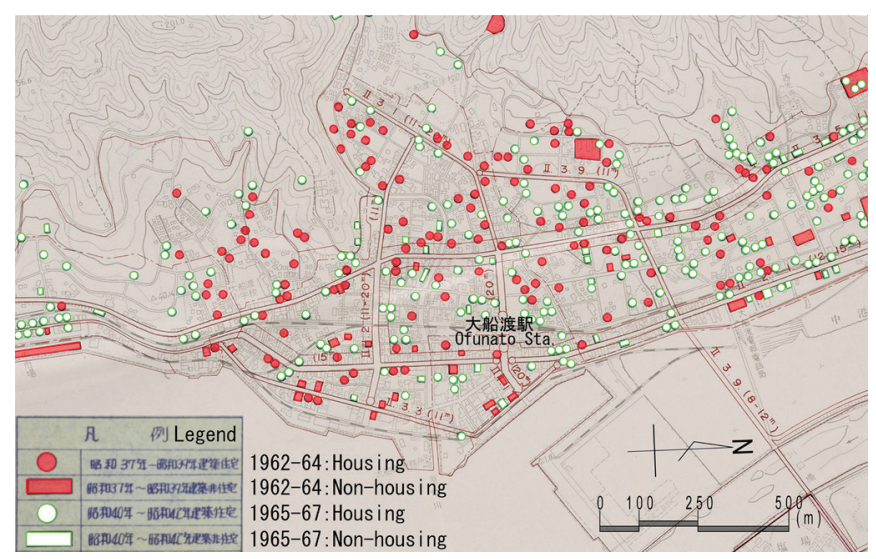

Fig.6 Building Dynamics in Ofunato Town (1962-67)

Source: National Archives of Japan, Emphasis added by the Quoter

Table4 Building Dynamics in Ofunato Town (1962-67)

\begin{tabular}{|c|c|c|c|c|c|c|}
\hline & \multicolumn{2}{|c|}{ Inside Fig.6 } & \multicolumn{2}{|c|}{$\begin{array}{c}\text { Coastal Area } \\
\text { (National Railway } \\
\text { East: Chayamae. } \\
\text { Nonoda) }\end{array}$} & \multicolumn{2}{|c|}{$\begin{array}{c}\text { Inside the } \\
\text { Fireproof } \\
\text { Building Belt }\end{array}$} \\
\hline & $\mathrm{n}$ & $\%$ & $\mathrm{n}$ & $\%$ & $\mathrm{n}$ & $\%$ \\
\hline $\begin{array}{l}<1962-64> \\
\text { Housing }\end{array}$ & 121 & 81.8 & 10 & 38.5 & 1 & 12.5 \\
\hline Non-housing & 27 & 18.2 & 16 & 61.5 & 7 & 87.5 \\
\hline Total & 148 & 100.0 & 26 & 100.0 & 8 & 100.0 \\
\hline $\begin{array}{l}<1965-67> \\
\text { Housing }\end{array}$ & 178 & 88.6 & 23 & 85.2 & 1 & 33.3 \\
\hline Non-housing & 23 & 11.4 & 4 & 14.8 & 2 & 66.7 \\
\hline Total & 201 & 100.0 & 27 & 100.0 & 3 & 100.0 \\
\hline $\begin{array}{l}<1962-67> \\
\text { Housing }\end{array}$ & 299 & 85.7 & 33 & 62.3 & 2 & 18.2 \\
\hline Non-housing & 50 & 14.3 & 20 & 37.7 & 9 & 81.8 \\
\hline Total & 349 & 100.0 & 53 & 100.0 & 11 & 100.0 \\
\hline
\end{tabular}

Source: National Archives of Japan, Arranged by the Quoter
Table5 Facilities by Purpose in Ofunato Town $(1964,68)$

\begin{tabular}{|c|c|c|c|c|}
\hline & \multicolumn{2}{|c|}{$\begin{array}{l}\text { Coastal Area (National } \\
\text { Railway East: } \\
\text { Chayamae } \cdot \text { Nonoda) } \\
\end{array}$} & \multicolumn{2}{|c|}{$\begin{array}{l}\text { Inside the Fireproof } \\
\text { Building Belt }\end{array}$} \\
\hline & $\mathrm{n}$ & $\%$ & $\mathrm{n}$ & $\%$ \\
\hline $\begin{array}{l}\qquad<1964> \\
\text { Exclusive Commercial Facility } \\
\text { 専用商業施設 }\end{array}$ & 24 & 5.9 & 12 & 10.5 \\
\hline $\begin{array}{l}\text { General Commercial Facility } \\
\text { 一般商業施設 }\end{array}$ & 160 & 39.0 & 43 & 37.7 \\
\hline Industrial Facility 工業施設 & 29 & 7.1 & 10 & 8.8 \\
\hline Housing Facility 住居施設 & 134 & 32.7 & 24 & 21.1 \\
\hline $\begin{array}{l}\text { Agriculture and Fishery Facility } \\
\text { 農漁業施設 }\end{array}$ & 0 & 0.0 & 0 & 0.0 \\
\hline $\begin{array}{l}\text { City Management Facility } \\
\text { 都市運営施設 }\end{array}$ & 28 & 6.8 & 12 & 10.5 \\
\hline Amusement Facility 娛楽施設 & 35 & 8.5 & 13 & 11.4 \\
\hline Welfare Facility 厚生施設 & 0 & 0.0 & 0 & 0.0 \\
\hline Government Office 官公署 & 0 & 0.0 & 0 & 0.0 \\
\hline Total & 410 & 100.0 & 114 & 100.0 \\
\hline $\begin{array}{l}\qquad<1968> \\
\text { Exclusive Commercial Facility } \\
\text { 専用商業施設 }\end{array}$ & 45 & 8.2 & 20 & 17.5 \\
\hline $\begin{array}{l}\text { General Commercial Facility } \\
\text { 一般商業施設 }\end{array}$ & 210 & 38.1 & 55 & 48.2 \\
\hline Industrial Facility 工業施設 & 120 & 21.8 & 24 & 21.1 \\
\hline Housing Facility 住居施設 & 140 & 25.4 & 6 & 5.3 \\
\hline $\begin{array}{l}\text { Agriculture and Fishery Facility } \\
\text { 農漁業施設 }\end{array}$ & 3 & 0.5 & 3 & 2.6 \\
\hline $\begin{array}{l}\text { City Management Facility } \\
\text { 都市運営施設 }\end{array}$ & 16 & 2.9 & 2 & 1.8 \\
\hline Amusement Facility 娛楽施設 & 16 & 2.9 & 4 & 3.5 \\
\hline Welfare Facility 厚生施設 & 1 & 0.2 & 0 & 0.0 \\
\hline Government Office 官公署 & 0 & 0.0 & 0 & 0.0 \\
\hline Total & 551 & 100.0 & 114 & 100.0 \\
\hline
\end{tabular}

Source: National Archives of Japan, Arranged by the Quoter

については不明が多く, 本稿で詳らかにできることは多くはないが、 いくつかの資料の照合によってその進捗をうかがうことを試みたい

\section{1. 防火建築帯周辺の建物の変化（1965 年前後）}

まず、防火建築帯の指定から比較的近い1965（昭和 40）年前後で ある。既報にも示した Fig. 6 には、1962～64（昭和 37～39）年と 1965 〜67 (昭和 40〜42) 年の 2 期に分けて、大船渡町周辺に、住宅とそ れ以外の建設がどの程度進んだかが示されている。これを Fig. 6 の 範囲について表にしたのが Table4 である。より内陸への建設が目立 ち、高台移転が進む一方で注63)、沿岸部への建設は捗々しくない。

また、Fig. 7 は、1964（昭和 39）年と1968（昭和 43）年の、大船 渡町周辺の用途別の建物図で、Table5 は、その範囲の棟数を示した ものである。この周辺は、当初準工業地域と商業地域として定めら れ、1969（昭和 44）年には商業地域がより広がる（Fig. 1）。そのた めか、主に店舗施設・工業施設・住居施設が建つ。国鉄大船渡線と 海で挟まれた範囲を見ると、この間、全体的に建物が増え、それに

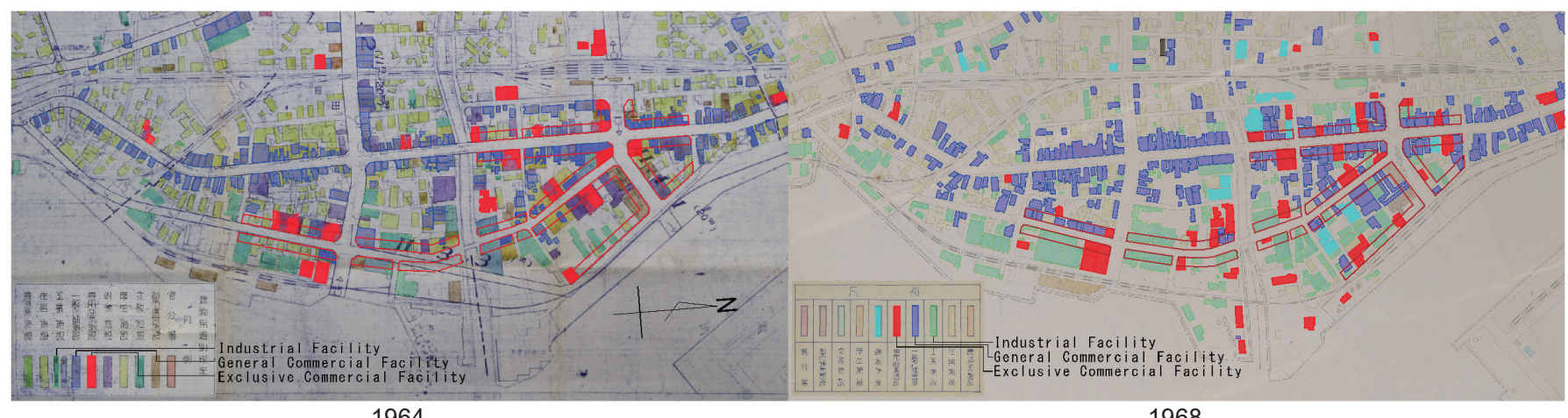

Fig.7 Facilities by Purpose in Ofunato Town 


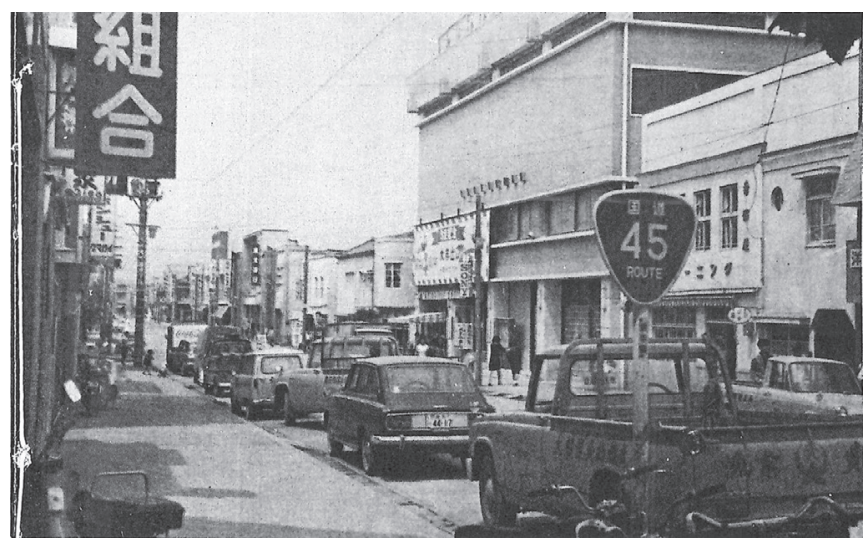

Photo1 Urban Area of Ofunato Town (1963-67)

Source: Ofunato City: City Directory, p.25, 1967 (the Univ. of Tokyo Library)

伴い空地が減る。用途別に見ると多いのは店舗施設だが、増加が著 しいのは工業施設である。店舗施設については、分類には専用商業 施設が別立てで設けられているから、ここでの一般店舗施設は店舗 併用住宅を指すと考えられる。専用と一般を比較すれば、一般店舗 施設の方が数は多く、防火建築帯の指定以前には、あってもごくわ ずかだったはずの専用商業施設も、少ないながら確実に増えている。

続いて、これを防火建築帯の範囲に限って見てみる。全体の棟数 に変化はないものの、店舗・工業施設が増え、住居施設は減る傾向 にあることが分かる。Fig. 7 の左右を比べると、複数棟が 1 棟にま とまったものもあるから、建物の大型化も起きている。

Photo1 は、1965（昭和 40）年頃の市街地である。この後、1972 （昭和 47）年には、歩道上に延長約 $600 \mathrm{~m}$ のアーケードが架けられ るといったように、利便を高め、商店街らしさを演出する施設が設 けられていく場所である注64)。正面には、大型の中高層建築物・大 船渡農協支所（1963（昭和 38）年）が建つ。しかし、その他多くは、 木造モルタルと思しき看板建築や瓦莫の勾配屋根の家屋であり、他 の都市で防火建築帯に建てられた帯状の建物が見当たらないのはも ちろん、鉄筋コンクリート造と思しき建物もほとんどない。

このように建設が進まない原因には、建設費の問題がやはりあっ たに違いない。どんなに補助や融資があっても、建て替えの負担は 大きい。この時期、日本全体では耐火建築物は増えているが、大船 渡では市全体で見ても（Fig. 4)、鉄筋コンクリート造は年に 1 万 $\mathrm{m}^{2}$ 建つ程度であった。県が、チリ地震対策事業の完成式典を 1967 (昭 和 42) 年に開き、「チリ地震津波の対策事業は 1966 年度に完了した」 注65) と寸ることも、防火建築帯造成事業の先細りを助長し、また裏 付けるものとなったかも知れない。

防火建築帯上の建設活動については、耐火建築物への建て替えの かなわない住民や商店主たちが、元々あった木造の建物を増改築し ながら使っていたとの証言もある注66)。大規模小売店舗や工場の他 には、銀行の支店や農協・ホテルもできたが、それらには、店名な どに見る限り、地元の資本を基調としないものも目に付く。

このように、指定からしばらく経っても、防火建築帯の範囲に耐 火建築物の林立する町並みができることはなかった。

\section{2. 防火建築帯周辺の土地利用と建物の変化}

建物以外にも注目して、防火建築帯の周辺に起こった、その後、 震災に至る比較的長期間の変化を見ていく。ただし、提示可能な資

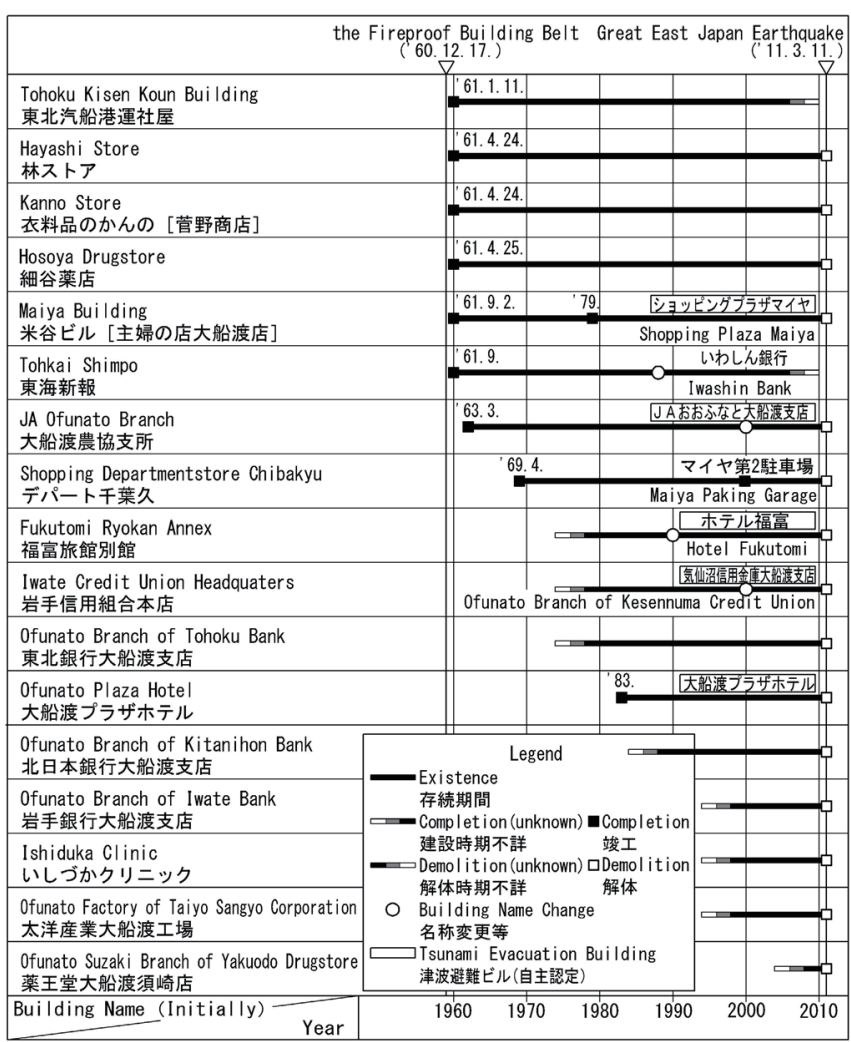

Fig.8 Main Construction Activities of Fire-resistive Buildings on the Fireproof Building Belt in Ofunato Town

Source: Author

料の制約のため、地図などを用いた検討の結果を記すに留める注67)。 まず、時代が下りるにつれて駐車場が増える。1952（昭和 27）年 の市制施行時を市域とする市の人口は、1985（昭和 60）年の 3.9 万 人をピークに減に転じ、そこに 90 年代以降には景気の低迷が加わる。 また、防火建築帯上では建て替えに当たって耐火建築物にすること が求められるから、負担の難しい住民がこの場所を離れたこともあ ろう。それらの影響によって空洞化現象が現れたものである。震災 の頃には、商店街もいわゆるシャッター商店街と化していた注68)。

一方、1980（昭和 55）年頃までは土地の分割も見られるが、その 後、土地はむしろ集約されていく。こうした中で、大規模小売店舗 や工場、ホテルなどの大型の建物が建っていたことになる。

土地利用の変化だけでなく、より具体的な建物の変化を、特に防 火建築帯上の建物に注目寸る。ここまでに挙げた中高層建築物に対 する融資や補助を受けた建物を中心に、その他に得られた写真や地 図などによる土地状況の変化から、防火建築帯上に建った耐火建築 物と思われる建物を拾い上げたのが Fig. 8 である。指定からしばら く経ってからも少しずつ建てられており、また、震災で被害を受け たか否かは別にして、多くは震災の頃まで残った。

\section{3. 東日本大震災時の防火建築帯周辺の建物}

次に震災時に注目寸る。Fig. 9 左図は、震災直前（2010（平成 22） 年) の都市計画図注69) に、防火建築帯の位置と、震災直後の 2011 (平 成 23) 年 6 月 2 日に市が発表した震災後の建物の被害調查結果の図 注70) から、「全壊」と判断された建物を示したもの、右図は、同月 7 日に撮影された航空写真注71) で現存する建物を示したものである。

ここで、市の調査での「全壊」は、凡例に「全壊（住宅流失・概 


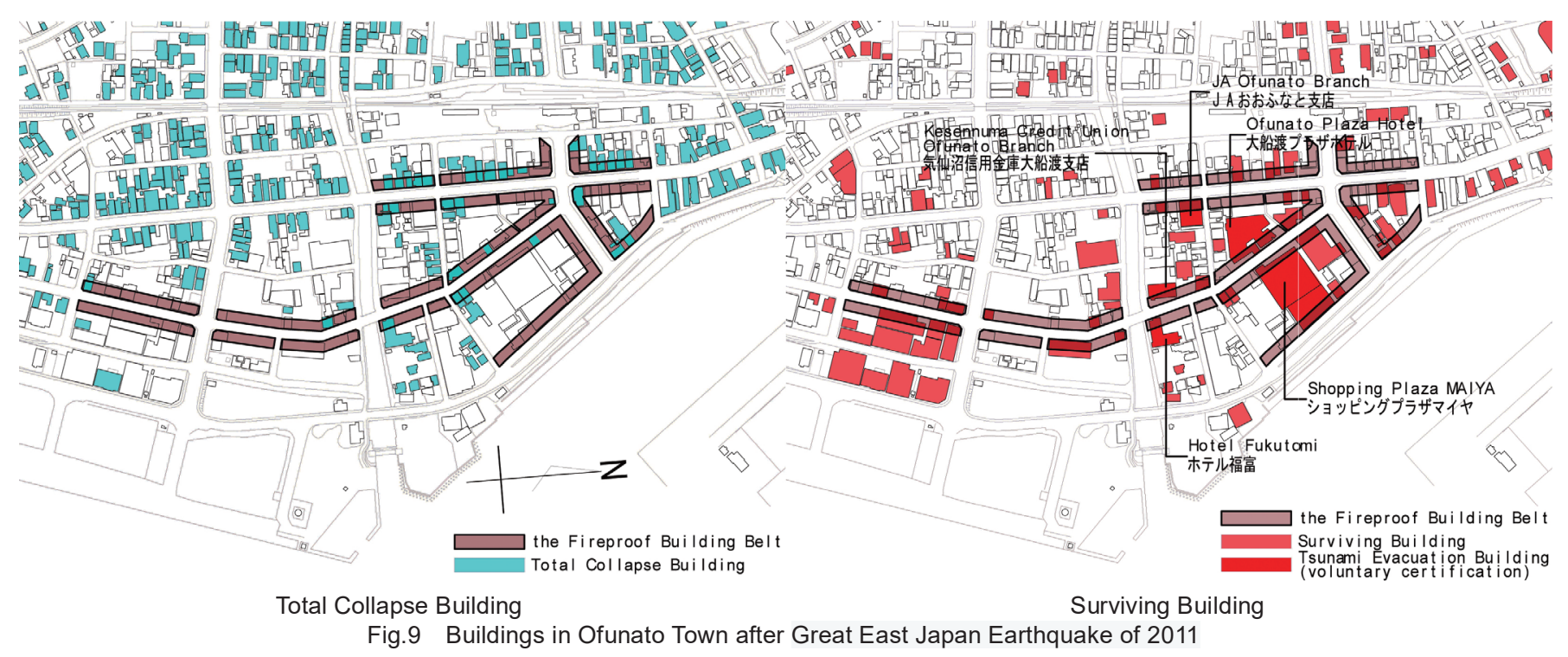

Source: Ofunato City: City Planning Map, 2010, (L): Ofunato City: Building Damage by District, p.6, 2011.6.2, (R): Geospatial Information Authority of Japan: Aerial Photo, 2011.6.7 (CTO20115-C25-22), Arranged by the Quoter

ね 1 階天井まで浸水)」とあるから、必ずしも建物が構造的に全壊し たこと意味しない。そのためか、ここで「全壊」となっていても、 航空写真で存在しているものもある注72)。また、Fig. 9 で左右両図と も色のつかない建物もある。この理由は不明だが、全壊してはいな いものの、残ってもいないことになるから、何かの理由で地図の作 製された震災前から震災直後までの間に解体されたことにならう。

ともあれ、この Fig. 9 から、震災直後、どこに建つどのような建 物が壊れたか、あるいは逆に残ったかが具体的に判明する。総じて、 小規模な建物が多く建っていたより内陸の建物は、震災で全壊の被 害を受けている (左図)。これら小規模な建物は、航空写真や住宅地 図に見る限り戸建の個人住宅と考えられる。それに対して、比較的 大規模な建物が多く建っていたより海側の建物は、震災後にも残っ ていたことが分かる(右図)。この残った、比較的規模の大きな建物 は、防火建築帯上にあるものが目立つ。

なお、前掲、建築防災が専門の森山らの調査によれば、震災当時 の大船渡では津波避難ビルは指定してはおらず、大船渡プラザホテ ル・ショッピングプラザマイヤ・ホテル福富・J Aおおふなと支店 (大船渡農協支所から改称) ・気仙沼信用金庫大船渡支店の 5 つが住 民と独自に自主協定を結ぶ形で非指定津波避難ビルとして使われる ことになっており、震災時には、実際にショッピングプラザマイヤ に 50 人、大船渡プラザホテルに 25 人が避難したという注 73$) 。$

これらは J Aおおふなと支店を除けば、全て 1970 年代半ば以降の 建設である (Fig. 8)。大船渡の防火建築帯造成の速度は、上で見た ように指定直後でもそれほど早くはなかった。そのため結果的に、 そこに建物が建つ頃には、土地が集約化され、建物は、大規模小売 店舗の登場が象徴するように大型化し、そのうちの防火建築帯上に 建ったものが津波避難ビルに自主認定され、中には実際に震災時に 避難に使われたものもあった、ということになる。

\section{5.まとめ}

本稿では、新聞資料や地図資料などを用いて、従来ほとんど知ら れることのなかった岩手県大船渡町に指定された最後の防火建築帯
に、(1)地元商店主たちがどのように反応したのか、(2)どのように耐 火建築物が計画され、建設されたのか、(3)その後、震災に向かう中 で防火建築帯周辺がどう展開したのかを探った。特に、(2)の指定後 の建設活動については、資料の制約もあって判明したものは必ずし も多くはなく、この点に課題も残るが、次のことを明らかにした。

(1)防火建築帯の指定に当たり大蔵省も補助に配慮し、地元行政も 前向きに捉える中、地元商店主たちも、新しい時代に向け、防火建 築帯上への共同建築建設の必要を感じていた。しかし、しばしば災 害に遭ってきた大船渡町で商売を営む者たちは資金に乏しく、新た に耐火建築物を建てることができる者は多くなかった。

そのため、(2)行政の予想に反して地元の建設需要は思った以上に 少なく、初年度には補助や融資に 20 件の申し込みと、それらを使っ て 2 年間で防火建築帯上に 8 件ほどの建設があった程度だった。そ して、防火建築帯の範囲を含め、大船渡町の市街地に建ったのは、 単独での建物を許容する建設省の意向もあったことが示すように、 多くが小規模の、それぞれの敷地の中に単独で建つ建物であった。

その後、(3)景気の低迷と人口の減少の中で、次第に駐車場として 使われる空地が増えていった。したがって、伊勢湾台風後、チリ地 震津波を経て考案された、対津波用の防潮帯としての耐火建築物が 帯状に建ち並ぶ町並みが完成することはなかった。

それでも、以後の長い時間の中では、土地の集約化現象も起こり、 大規模小売店舗の進出などによって規模の大きな建物も建てられた。 それが、結果的には自主認定の津波避難ビルとなり、中には震災の 折の避難に使われたものもあった。その意味では、後の建設の需要 や施策に補強された面はあるものの、防火地域となる防火建築帯の 指定がなければこうした建物が建つこともなかったかも知れないと 考えると、防火建築帯指定の効果はあったことにはなろう。

なお、震災後、かつて防火建築帯に指定された周辺は、防火地域 から準防火地域に下げられ、また、災害危険区域に指定され、居住 が禁止されて現在に至っている注74)。

謝辞 
本研究の遂行に際しては、大船渡市役所・市議会・市立図書館はじ め多くの協力を得ました。また、森山修治先生（日本大学工学部教 授)には貴重なご教示をいただきました。記して御礼申し上げます。

\section{参考文献}

1) Kaneno, K: Record of Disaster of the Chilean Tsunami, Ofunato City, 1962 (in Japanese) 金野菊三郎編：大船渡災害誌，岩手県大船渡市, 1962

\section{注}

○用文中の [ ] は引用者による。

○以下、『東海新報』は大船渡市立図書館所蔵資料。『岩手日報』は国立国会 図書館所蔵資料。

注 1）拙稿：大船渡町の防火建築帯の指定とその背景, 日本建築学会計画系 論文集, Vol.85, No.778, pp.2761-2771, 2020.12

注 2）中島直人・田中暁子：巨大津波に向き合う都市計画 津波に強いまちづ くりに向けて, 都市問題, Vol.102, No.6, pp.4-14, 2011.6

注 3）森山修治：東日本大震災直後に実施した津波避難ビルの調査記録 一自 治体へのヒアリング調查記録と津波避難ビルの効果と被害一, 第 62 回日本 大学工学部学術研究報告会建築学部会 講演要旨集, pp.71-74, 2019.12

注 4）大船渡市史編集委員会編：大船渡市史 第二巻 沿革編，大船渡市，1980

注 5）大船渡市役所庶務課調查広報係：大船渡市市勢要覧, p.17, 1968

注 6）なお、大船渡市は防災建築街区造成法の適用にはなっていない。

注 7) 拙稿: 大船渡市の防火建築帯指定後の展開について, 日本建築学会大会 学術講演梗概集（建築歴史・意匠）, pp.495-496, 2021.9

注 8）復興事務局告示板, 東海新報, p.1, 1960.6.24

注 9）買物は地元商店から 大船渡専門店会が運動，東海新報, p.1, 1960.7.3

注 10）商店街の診断結果 山の手移転には賛成しない, 東海新報, p.1, 1960.8. 17

注 11）大船渡市の将来のために，東海新報, p.1, 1960.8.18

注 12) 商店にモダン感覚を 大船渡商店街を外部診断, 東海新報, p.1, 1960.9.4 注 13）えびす顔で算盤はじく 大船渡商和会... .6 大売出しの総決算, 東海新

報, p.1, 1961.1.8.・おわび 大船渡商和会, 東海新報, p.2, 1961.3.9

注 14）岩手県 - 大船渡市編：大船渡市商店街診断商圈調查報告書, 1963 （岩 手県立図書館所蔵資料)

注 15）前掲注 14）, 緒言

注 16）前掲注 14）, pp.23-29

注 17）岩手県 · 大船渡市編：大船渡市広域商業診断報告書, 1969（岩手県立 図書館所蔵資料)

注 18）中高層建築物について, 東海新報, p.1, 1960.6.21

注 19）防火地域設定座談会 住宅・店舗・倉庫などどう復興させるか, 東海新 報, p.2, 1960.7.12

注 20）前掲注 14）, pp.19-20

注 21）菅原貫一：チリ地震津波被害地から 災害に直面して知る組織化の威 力について, 中小企業と組合, Vol.15, No.9, pp.66-69, 1960.9

注 22）被災地之の後(3) 大船渡市 上, 岩手日報, p.3, 1960.6.2

注 23）防火地帯など認可さる 大船渡の恒久復興対策の焦点, 東海新報, p.1, 1960.8 .2

注 24）なお、この移転数の実態を明らかにする資料は見当たらない。

注 25）前掲注 14）, pp.11-12

注 26) 大船渡市役所庶務課調査広報係：岩手大船渡 市勢要覧, p.25, 1967 (東 京大学経済学部図書館所蔵資料)

注 27）大船渡市：大船渡市総合開発計画書 昭和 40 年度調整, p. 12,1965 (東 京大学経済学部図書館所蔵資料)

注 28）大船渡市役所庶務課調査広報係：大船渡市勢要覧, p.11, 1972（岩手県 立図書館所蔵資料)

注 29）開発計画に津波対策を 東北開発研究会でまとめる, 岩手日報, p.1, 1960.6.21 (国立国会図書館所蔵資料)

注 30) 建設省宅地課・西脇弥佑の文（防火建築带と防災建築街区の造成事業, 建築行政, Vol.10, No.56, pp.4-7, 1961.8) には実際に $280 \mathrm{~m}$ に補助が付いた とある。なお、大船渡市には、災害復旧補助の意味もあって、1961（昭和 36 ）年度にも、造成延長 $49 \mathrm{~m}$ 分の補助（257 万 2 千円）が付いている。

注 31）住宅地図出版社：大船渡市 1970 (ゼンリンの住宅地図）, 1970 との 照合による。本来は 1960 年前後の資料が望ましいが、見当たらないため、
得られる中で最も近い 1970 年のものを用いた。

注 32）市街地に美しいビル 公庫で高額の補助融資，東海新報, p.1, 1960.6 18

注 33）防災に中高層建築 住宅金融公庫で申込受付，東海新報, p.2, 1960.6. 30

注 34）中高層建築に強い関心 申込件数 35, 東海新報, p.1, 1960.7.1

注 35）防火帯の指定を申請 中高層希望は目下 12 件，東海新報, p.1, 1960.7. 26

注 36）大船渡市の防災都市化 建設省、大蔵省に予算要求，東海新報，p.1, 19 60.11 .15

注 37）事業の促進と高率補助要請, 東海新報, p.2, 1960.11.26

注 38）談話室，東海新報, p.1, 1960.12.1

注 39) 高率補助獲得に声援, 東海新報, p.1, 1960.12 .2

注 40）前掲注 38)

注 41）チリ津波対策事業費 3 分の 2 の国補率きまる, 東海新報, p.1, 1960. 12.6

注 42）大蔵省も積極的 大船渡市の防火建築帯, 東海新報, p.1, 1960.11.27 注 43）前掲注 42） なお、12 月 14 日の記事（建てやすくなります？防火 帯の中高層建築に朗報，東海新報, p.1, 1960.12.14)では 14 件とあるため、 Table3 ではこの数字を用いた。

注 44）貸付 2 件がまず決定，東海新報, p.1, 1960.12.25

注 45）陽春に堂々の威容 相次ぐ“中高層” の建設譜, 東海新報, p.2, 1961.1.11 注 46）参考文献 1），p.180

注 47）前掲注 33)

注 48）防火帯の中高層 まだまだワクに余裕 大船渡市建設課 建築希望者募

集に躍起，東海新報, p.1, 1961.2.28

注 49) 衆議院事務局：第 38 回国会衆議院建設委員会議録, No.3, p.5, 1961.2.8 注 50）建てやすくなります？防火帯の中高層建築に朗報，東海新報, p.1,

1960.12 .14

注 51）前掲注 44）

注 52）この時期の膨大な都市計画事業の支出を懸念する声は市議からも出た。

(例えば第 4 回定例会における小山勝雄の質疑（大船渡市議会事務局：大 船渡市議会第四回定例会会議録, 1961.11.29（大船渡市議会所蔵資料））。

注 53）防火帯の造成はかる 大船渡市 補助金交付条例を制定，東海新報, p.1, 1961.3.31 なお、「現在すでに建築工事中の耐火建築物についてはこの条 例は適用される」とした。また、この議会では防火建築帯造成事業費補助 金を、年度をまたいで繰り越し使用することが採決された（大船渡市議会 第二回臨時会会議録, 1961.3.28 (大船渡市議会所蔵資料))。

注 54）きよう 富山市内視察 大船渡市議団の陳情、研修旅行，東海新報, p.1, 1961.5 .9

注 55）スーパーマーケット開店，東海新報, p.1, 1961.2.26

注 56） 24 日に同時開店 大船渡町にデラックス商店が 2 カ所，東海新報, p.1, 1961.4 .18

注 57）本日開店 細谷薬店，東海新報, p.1, 1961.4.25

注 58）主婦の店いよいよ開店，東海新報, p.1, 1961.9.1

注 59）本社の新社屋近く完成，東海新報, p.1, 1961.9.17

注 60）本社々屋など 8 月完成か 遅れている大船渡町の中高層建築, 東海新 報, p.1, 1961.6.16

注 61）参考文献 1), p.111

注 62）この時期、街路樹の復元や追加も行われた（街路樹の手入れ 施設の

花壇作り 盛高農業クラブ 春休みに奉仕, 東海新報, p.1, 1961.3.2や、大船 渡町の植樹祭 きよう地区公民館の音頭とりで，東海新報, p.1, 1961.4.9)。 注 63）山の手は建築ブーム 津波の安全地帯, 東海新報, p.1, 1960.8.23 注 64）大船渡市史編集委員会編: 大船渡市史 第六巻 通史編，大船渡市， p.886 • p.889, 2002 注 65) 岩手県: 岩手県土木概要 昭和 42 年版, p.89, 1967 注 66) 大船渡市災害復興局ご担当者の教示 (2019 年 6 月 28 日)。 注 67）1970 年以降の毎年の『ゼンリンの住宅地図』の照合などによる。

注 68）金野尚一：申出換地による復興まちづくり 大船渡駅周辺地区土地区 画整理事業, 区画整理, Vol.60, No.9, pp.29-31, 2017.9 注 69）大船渡市災害復興局提供資料（2019 年 6 月 28 日）。 注 70）大船渡市：地区別の被害状況について, p.6, 2011.6.2 注 71）釜石 ·大船渡（CTO20115-C25-22）2011.6.7 (国土地理院所蔵資料) 注 72）防火建築帯の範囲には 30 棟ほどの建物が残っている。 注 73）前掲注 3)

注 74) 大船渡地区への災害危険区域の指定は、2014 (平成 26) 年 9 月 30 日。 


\title{
CONSTRUCTION AFTER APPLICATION OF THE FIREPROOF BUILDING BELT IN OFUNATO TOWN
}

\section{Kiyotaka HAYAMI*1}

\author{
* 1 Prof., Dept. of Architecture, College of Engineering, Nihon Univ., Ph.D.
}

The purpose of this study is to clarify the development of construction activities by fire-resistive buildings on the Fireproof Building Belt (FBB) as seawall in Ofunato Town, Ofunato City, Iwate Prefecture after the Chilean Tsunami of 1960.

At first, the author tried to find how the Shopkeepers in this town thought the idea of construction of seawall by fire-resistive buildings on the coastal area before and after application of FBB. By reviewing administrative documents and newspaper articles, shopkeepers and government officials did not think to move their shops from coastal land to higher land. Instead of moving, government officials thought to reconstruct shops by fire-resistive buildings. Many shopkeepers expected to realize the townscape of reinforced concrete structure buildings as fire-resistive buildings after application of FBB. This reason was that they felt threatened by the opening of the supermarket, which was one of the nationwide supermarket chains in Japan, to this town. This fact indicated that they had understood the necessity that kind of buildings for them to create their new era.

Nevertheless, the Shopkeepers had no financial power, because many of them were newcomers and war repatriates. Then there were not enough people who could prepare money to construct that kind of buildings. Consequently, the government subsidy was too much to digest for them. Only eight fire-resistive buildings had constructed on FBB for two years after application. Therefore, although Ofunato City applied FBB, people in this town chose to construct their housings on higher land by wood structure. They could not construct enough mount of reinforced concrete structure building on coastal land, which included FBB.

In the 1980s, the land consolidation around FBB progressed and large buildings were constructed. After the 1990s, it showed the hollowing-out phenomenon on this area and the parking lots became to be conspicuous.

At Great East Japan Earthquake of 2011 (GEJE), Many buildings in this town were damaged. In comparison with the buildings on coastal land, the damage was more severe the buildings on higher land. The surviving buildings on coastal land were fire-resistive buildings. Among them, there were five buildings were used to evacuate as Tsunami Evacuation Building by self-certification at GEJE. If Ofunato City did not apply FBB in 1960, we could think that kind of buildings did not construct on the coastal area of Ofunato Town. In that sense, FBB was, to some extent, an effective policy. 